
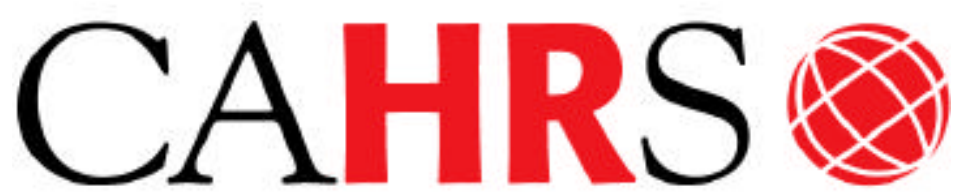

Center for Advanced Human Resource Studies
CAHRS / Cornell University 187 Ives Hall

Ithaca, NY 14853-3901 USA

Tel. 607 255-9358

www.ilr.cornell.edu/CAHRS/

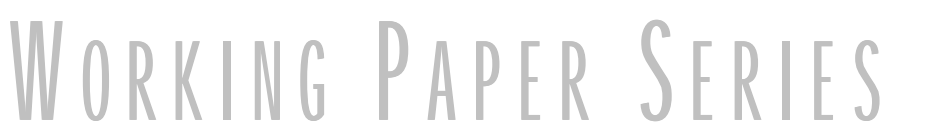

\title{
Human Resource Strategies and Firm Performance: What Do We Know and Where Do We Need to Go?
}

\section{Lee Dyer \\ Todd Reeves}

Working Paper 94 - 29 


\title{
Human Resource Strategies and Firm Performance: What Do We Know and Where Do We Need to Go?
}

\author{
Lee Dyer \\ School of Industrial and Labor Relations \\ Center for Advanced Human Resource Studies \\ Cornell University \\ Ithaca, NY 14853-3901 \\ and \\ Todd Reeves \\ AT\&T - Global Information Solutions \\ West Columbia, SC
}

Working Paper 94-29

\begin{abstract}
http://www.ilr.cornell.edu/cahrs
Paper prepared for presentation at the 10th World Congress of the International Industrial Relations Association

Washington, DC, May 31 - June 4, 1995
\end{abstract}

This paper has not undergone formal review or approval of the faculty of the ILR School. It is intended to make results of Center research, conferences, and projects available to others interested in human resource management in preliminary form to encourage discussion and suggestions. 
Strategic human resource management (SHRM) has emerged as a, if not the, major paradigm among scholars and practitioners in many parts of the world. This is apparent from the recent literature on international human resource management (e.g., Schuler, Dowling, and De Cieri, 1993), as well from recent reviews of trends in the U.S. (Dyer and Kochan, 1994), Canada (Betcherman, McMullen, Leckie, and Caron, 1994), and the U.K (Lundy, 1994).

SHRM's spreading popularity owes much to an explicit promise of enhanced organizational effectiveness which can be achieved, according to the dominant models, by developing internally consistent bundles of human resource practices -- human resource strategies -- which are properly matched or linked to extant organizational contexts, most notably business strategies (Dyer and Kochan, 1994; Milliman, Von Glinow, and Nathan, 1991.

The veracity of this promise is explored here. First, we briefly examine the logic of the underlying theories or assumptions and, then, review the applicable, albeit limited, research. The idea is to provide answers to the following questions:

(1) Why should firms bundle their human resource practices? To what extent, and in what ways, do they?

(2) Does bundling produce positive organizational results?

(3) Is there one best bundle, or does it (as the contingency theorists contend) all depend?

\section{THE LOGIC AND PREVALENCE OF BUNDLING}

Human resource practices are said to be bundled when they occur in fairly complete, mutually reinforcing or synergistic sets (Dyer and Holder, 1988; Dyer and Kochan, 1994). The logic in favor of bundling is straightforward. First, since employee performance is a function of both ability and motivation, it makes sense to have practices aimed at enhancing both. Second, since employee performance is an "over-determined phenomenon" (Hackman, 1985), it is most likely to be maximized when influenced by non-independent activities which are deliberately redundant (MacDuffie, in press). Thus, best results should be obtained when there are several ways for employees to acquire needed skills (e.g., careful selection, on- and off-the-job training, etc.) and multiple incentives to enhance their motivation (e.g., peer pressure, monetary and nonmonetary rewards, etc.). (This, of course, raises but does not answer the questions of how much and what types of redundancies are optimal from a benefit - cost point of view.)

The logic of bundling has inspired several attempts to build typologies of human resource strategies; that is, to construct conceptually defensible packages of mutually reinforcing or synergistic human resource practices. Such typologies are typically based on selected case studies. Examples include Walton's (1985) well-known Control and Commitment dichotomy; Dyer and Holder's (1988) Inducement, Investment, and Involvement trichotomy; 
Begin's (1991) carefully crafted set of five "employment policy systems"; and Dunlop's (1994) elaboration of eight strategic types. (For a fuller review of this literature, see Dyer and Kochan, 1994).

Similarly, the logic of bundling has inspired a small number of survey studies designed to derive taxonomies of human resource strategies (and to uncover the antecedents and consequences of the resulting configurations). Those of which we are aware are briefly described in Exhibit 1.

\section{Exhibit 1: Characteristics of Significant Studies}

\begin{tabular}{|c|c|c|}
\hline AUTHOR & SAMPLE & METHODOLOGY \\
\hline ARTHUR (1994) & $\begin{array}{l}30 \text { steel minimills in the U.S. } \\
\text { covers production and } \\
\text { maintenance employees }\end{array}$ & $\begin{array}{l}\text { Data collected by surveying HR managers } \\
\text { (except business strategy data provided by } \\
\text { top line managers). Taxonomy of HR } \\
\text { strategies ("human resource systems") } \\
\text { derived using Ward's cluster analysis } \\
\text { technique. Dependent variables were labor } \\
\text { productivity, quality, and employee } \\
\text { turnover. }\end{array}$ \\
\hline ICHNIOWSKI (1990) & $\begin{array}{l}255 \text { Manufacturing firms in the } \\
\text { U.S. Unit of analysis is "business } \\
\text { lines" (often corresponding to a } \\
\text { division of a company). Covers } \\
\text { production employees. }\end{array}$ & $\begin{array}{l}\text { Data collected by survey HR directors. } \\
\text { Taxonomy of HR strategies ("human } \\
\text { resource management systems") derived } \\
\text { using Wong and Lane's K-th nearest } \\
\text { neighbor clustering procedure. Dependent } \\
\text { variables were labor productivity and stock } \\
\text { market value (Tobin's q). }\end{array}$ \\
\hline $\begin{array}{l}\text { ICHNIOWSKI, SHAW, } \\
\text { and PRENNUSHI } \\
(1993)\end{array}$ & $\begin{array}{l}30 \text { steel finishing lines in } 21 \text { steel } \\
\text { companies in the U.S. Covers } \\
\text { production employees. }\end{array}$ & $\begin{array}{l}\text { Data collected through standardized, but } \\
\text { open-ended interviews with HR managers, } \\
\text { operations managers, etc. Taxonomy of } \\
\text { HR strategies ("HRM Systems") derived } \\
\text { using nominate, a maximum productivity } \\
\text { and, parenthetically, quality. }\end{array}$ \\
\hline MacDUFFIE (in press) & $\begin{array}{l}62 \text { high volume auto assembly } \\
\text { plants worldwide. Covers } \\
\text { production employees. }\end{array}$ & $\begin{array}{l}\text { Data collected by sending surveys to a } \\
\text { contact person in each plant, who then } \\
\text { distributed different sections to appropriate } \\
\text { departmental managers. Taxonomy of HR } \\
\text { strategies ("bundles") determined using } \\
\text { cluster analysis of three pre-determined } \\
\text { scales-buffers, work system, and HRM } \\
\text { policies. Dependent variables were } \\
\text { productivity and quality. }\end{array}$ \\
\hline
\end{tabular}

While the typology literature (and especially Walton's [1985] dichotomy) often informs the interpretation of the taxonomical studies, the same has not been true with respect to the up-front designs. As a result, these studies include a bewildering array of input variables. Exhibit 
2 clarifies this point. Note, for example, that the number of human resource practices measured in these studies varies from a low of six (Ichniowski, 1990) to a high of 11 (MacDuffie, in press). Further, there are 28 different input measures across the four studies. Only one -- formal training -- shows up in all four studies; only three -- incentives/gain-sharing plans, employee participation or involvement, and due process procedures -- show up in three of the four studies. Twenty-two of the 28 human resource practices appear in only one study.

EXHIBIT 2

HUMAN RESOURCE POUCIES AND PRACTICES MEASURED

\section{AUTHORS (WTH NUMBER OF POUCIES AND PRACTICES IN PARENTHESES)}

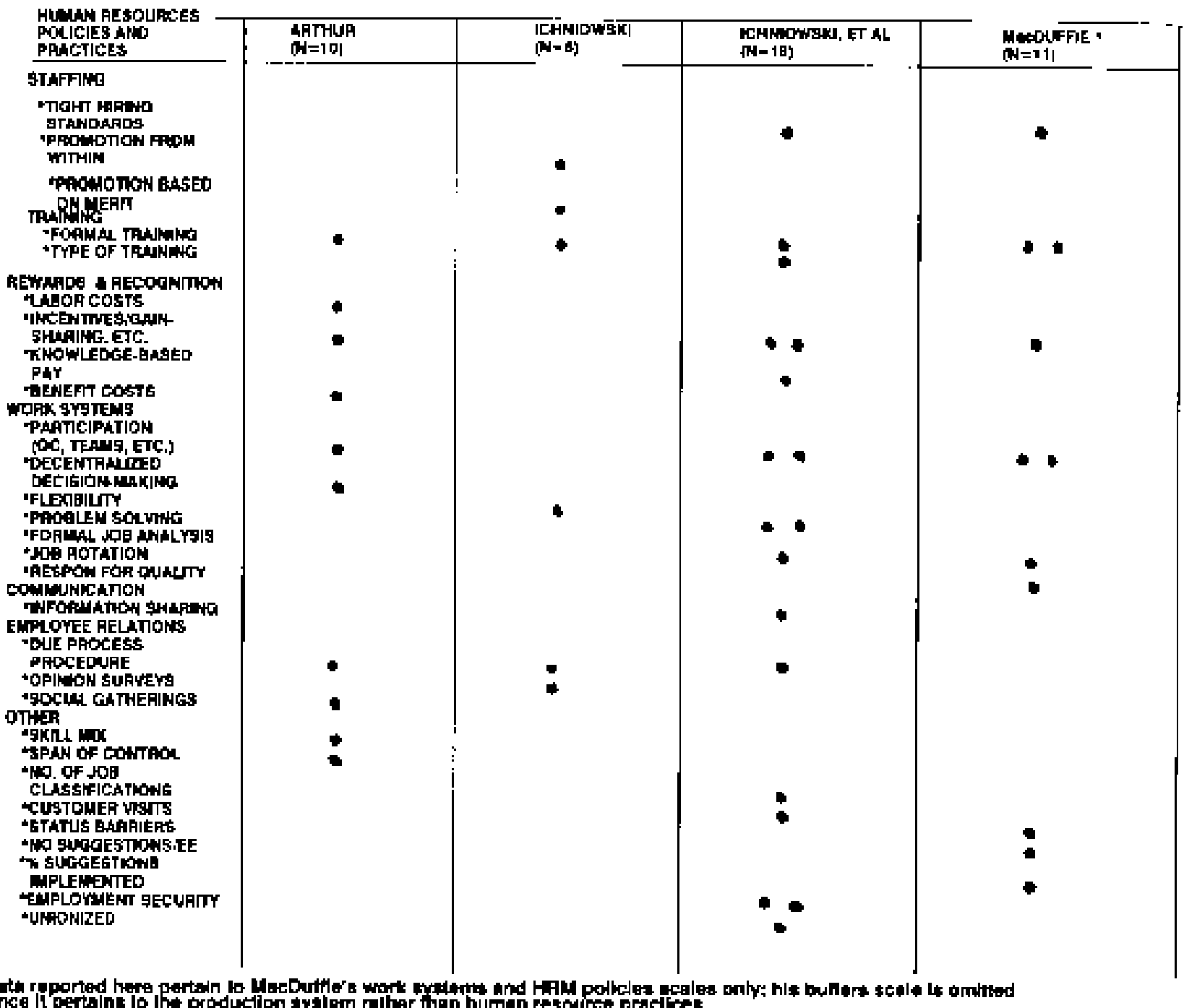

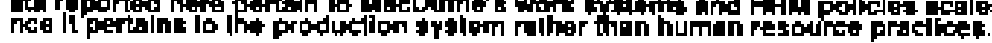

What about the resulting taxonomies? Exhibit 3 provides a summary of these. Arthur (1994), studying U.S. steel minimills, derived two types -- synthesized from six clusters identified 
in earlier analyses (Arthur, 1990, 1992). MacDuffie (in press), looking at auto assembly plants worldwide, identified three strategies. Ichniowski, Shaw, and Prennushi (1993), focusing on finishing operations in 21 large steel mills in the U.S., came up with four models, while Ichniowski (1990), using survey data from 255 large manufacturing firms also in the U. S., derived nine. These differences are not surprising, given the variations in input measures and samples noted above and the authors' choices of data analytic techniques (described briefly in Exhibit 1).

More surprising, perhaps, is the tendency of the various taxonomies to array in reasonably comparable continua from, in the authors' terms, "Traditional", "Control", and "Mass Production" strategies on one end to "Innovative", "Commitment", and "Flexible (or Lean) Production" strategies on the other (as shown in Exhibit 3). Some similarities exist in the components of the anchoring strategies. All four "Traditional" models, for example, are characterized by fixed job designs, minimal employee participation, and low levels of formal training, while all four "Innovative" models exhibit opposite features. There are some glaring inconsistencies across the anchoring strategies. For example, Arthur's (1994) "Control" model contains incentive/bonus plans, while MacDuffie's (in press) "Mass Production" model is characterized by non-contingent compensation.

The data show that between 10\% (Ichniowski, 1990) and 50\% (MacDuffie, in press) of the firms studied followed a "Traditional", "Control", or "Mass Production" human resource strategy (Arthur's [1990, 1992] original cluster analysis showed 27\%.) Comparable figures for the "Innovative", "Commitment", or "Flexible (or Lean) Production" strategy are between 10\% (Ichniowski, 1990) and 25\% (MacDuffie, in press). (Arthur [1990,1992] found 23\%.) This means that between one-quarter and four-fifths of the firms studied had human resource practices which were not obviously bundled; that is, they had human resource strategies (if that is the right term) characterized as "Mixed" or "Transitional" (or which could not be classified).

In brief, while logic supports the notion of bundling human resource practices, theoretical and empirical attempts to define the components and measure the contents and prevalence of bundles, while individually impressive, are collectively deficient and confusing. As a consequence, we have but a bare inkling of the number of firms which are actually managing at least some of their human resources strategically, and of the types of strategies they are using.

\section{BUNDLING AND ORGANIZATIONAL EFFECTIVENESS}

Theoretically, as noted above, bundling should promote organizational effectiveness. At a minimum, bundles should produce greater performance effects than any of the individual human practices of which they are composed. But, it is unlikely that all bundles are created 
equal; that is, some types should produce greater performance effects than others. Here we explore both issues.

First, a word about organizational effectiveness. In research pertaining to human resource strategy, there are several types of outcomes which might apply (Dyer, 1984). The three most defensible are: (1) human resource outcomes such as absenteeism, turnover, and individual or group performance; (2) organizational outcomes such as productivity, quality, and service; and (3) financial or accounting outcomes such as return on invested capital or return on assets. A fourth possibility, for publicly held firms, is stock market performance as measured by stock value or shareholder return.

Alas, in research trade-offs must be made. The face validity of these outcomes goes in the order presented. That is, human resource strategies are likely to have their most direct effects on human resource outcomes, next greatest on organizational outcomes, and so forth. This reflects, in part, what such strategies are designed to do and, in part, the complexity of factors which affect outcomes such as profitability, not to mention stock prices. And yet, from a strategic standpoint, human resource outcomes are probably deficient outcomes in the eyes of most managers, whose strategic goals certainly extend to organizational outcomes and probably beyond these to the bottom-line (and if they have stock options, perhaps all the way to Wall Street). These trade-offs may explain why the research thus far has focused primarily on organizational outcomes, especially productivity and quality, and only marginally on the other three types.

\section{BUNDLES VS. THEIR INDIVIDUAL COMPONENTS}

Only one study specifically examined the bundles vs. individual components question. Using regression models with multiple control variables, Ichniowski, et al (1993) found small, but statistically significant, positive relationships between productivity (uptime of steel mill finishing lines) and most of the 18 human resource practices examined. Focusing in on ten of the human resource practices which were significantly changed during the course of their study, they found that seven resulted in productivity improvements in the range of one to two percentage points.

The effects of the 18 individual human resource practices and the 10 changes, however, were virtually eliminated when measures of "human resource systems" (the four noted in Exhibit 3 ) were entered in the various regression equations. Based on this and related evidence, the authors concluded that "[s]ystems of IIRM policies have bigger productivity effects than the sum of any ... effects due to individual practices" (p. 48) and, concerning change, that "[m]arginal changes in individual policies have little or no effect on productivity. Improving productivity 
requires substantial changes in a set of HRM policies" (Ichniowski, et al, 1993, p. 37, italics in original).

\section{BUNDLES VS. BUNDLES}

Four studies have examined the relative effects of various bundles of human resource practices on productivity, three of these also included a quality measure. Ichniowski, et al (1993), in addition to comparing bundles against their individual components, also compared their four systems (see Exhibit 3) in terms of both productivity and quality. In terms of productivity (line uptime), the "Innovative" system significantly outperformed the two "Mixed" systems (by about eight percentage points) which, in turn, outperformed the "Traditional" system (by about three percentage points). With respect to quality ("prime yield" rates), the pattern was nearly the same: the "Innovative" system outperformed the better of the two "Mixed" systems (by about five percentage points) which, in turn, outperformed the remaining two systems (also by about five percentage points).

Comparing steel minimills having a "Commitment" human resource strategy with those having a "Control" strategy (again, refer to Exhibit 3), Arthur (1994) found that the former had both significantly higher levels of productivity (i.e., fewer labor hours per ton of steel produced) and significantly higher levels of quality (i.e., lower scrap rates).

In MacDuffie's (in press) study, higher levels of productivity (i.e., fewer hours per vehicle produced) prevailed in auto assembly plants with "Flexible (or Lean) Production" systems than in those with either "Transitional" or "Mass Production" systems (which were not significantly different from one another). Quality (J.D. Power's 1989 survey of new car buyers) was also higher in the plants with "Flexible (or Lean) Production" systems; in addition, those with "Transitional Production" systems had significantly higher quality than those with "Mass Production" systems. The combination of work systems and human resource policies only (i.e., omitting the buffers component, as noted in Exhibit 2) produced the same result with respect to productivity, but not quality. The complete regression models explained more variance in productivity than in quality. But, because more of the variance in the former was explained by the control variables used in the analyses, the human resource strategy variables actually explained more of the variance in quality than in productivity.

The across industry survey reported by Ichniowski (1990) compared the productivity effects of the "Commitment" model against the eight others identified through cluster analysis (see Exhibit 3) and, once again, the "Commitment" model proved superior.

The only study which included a human resource outcome (Arthur, 1994) found human resource strategy to be significantly related to employee turnover rates. The average turnover 
rate in minimills with a "Commitment" strategy was less than half that in minimills with a "Control" strategy (annual rates of three and seven percent, respectively). (In an interesting subanalysis, Arthur also found that while employee turnover was negatively related to productivity and quality among minimills with a "Commitment" strategy, no comparable relationship prevailed among those with a "Control" strategy. He suggested that in the latter case the relationship may be curvilinear; that is, employee turnover may have no effect on organizational outcomes in minimills with minimal investments in employees up to some point, but as rates exceed that point they may become dysfunctional. At any rate, the moderating effect of human resource strategy on relationships between human resource and organizational outcomes is certainly an interesting avenue for future exploration.)

Ichniowski (1990) also looked at the effects of human resource strategies on stock market performance (Tobin's $q$ ). The results were consistent with those reported earlier. That is, the "High Commitment" model was more strongly related to Tobins $q$ than were any of the remaining eight models. But, as would be expected, the amount of variance explained in this variable was only about $25 \%$, compared with about $85 \%$ of variance explained in productivity (with the same control variables appearing in both models).

\section{SUMMARY}

Ichniowski, et al (1993) make a strong case for the value of bundling, although clearly more studies in more industries among more employee groups are needed. And, of course, the benefit - cost question raised earlier remains to be answered.

More interesting, perhaps, is the consistent support for the superiority of the "Innovative", "Commitment", and "Flexible (or Lean) Production" models. Notwithstanding considerable variation in methodological approaches, and their attendant difficulties, this pattern holds across three industry studies (one each in autos, big steel, and minimills) and a broad survey, and across four different types of organizational effectiveness measures.

But, as noted earlier, while there are similarities, the contents of the "Commitment", "Involvement", and "Flexible (or Lean) Production" models are far from identical. Employee involvement anchors all four of the models cited (see Exhibit 3). But (as noted earlier), there is considerable variation in the conceptualization and measurement of this construct-a direct measure, the prevalence of flexible work designs, use rates of various types of teams, etc. Careful selection, extensive training, and contingent compensation are the only other attributes to appear in majority of the five models.

This variation raises an interesting issue: To what can the consistently solid support for the "Innovative", "Commitment", and "Flexible (or Lean) Production" models be attributed? If 
their similarities outweighed their differences, we could perhaps conclude that there is, indeed, a superior human resource strategy out there. But, this does not seem to be the case. Perhaps these models are picking up other attributes to which they are indirectly related. For example, they may represent generally similar broad philosophies of human resource management which have positive performance effects irrespective of the specific human practices used in their implementation. This possibility has been raised by Kochan and Osterman (1994) (in their "Mutual Gains" model), and even more explicitly by Pfeffer (1994). Another possibility is that these models represent even more fundamental and basic underlying variables, such as trust; this notion received some support in the interviews conducted by Ichniowski, et al (1993) in the steel mills, and was suggested as well by Kochan and Osterman (1994). Or, perhaps, it is simply that these "high end" models require and receive considerably more care and attention than do the others both in terms of design and construction, and what is being picked up in the various studies is an interesting variation on the well-known (if not universally accepted) Hawthorne effect. 
Exhibit 3: Typologies of Human Resource Strategies

\begin{tabular}{|c|c|c|c|c|}
\hline \multicolumn{5}{|c|}{ TYPES (WITH REPRESENTATIVE CHARACTERISTICS) } \\
\hline AUTHOR & $\begin{array}{l}\text { NO. OF } \\
\text { TYPES }\end{array}$ & "TRADITIONAL" TYPES & MIXED TYPE(S) & "INNOVATIVE" TYPES \\
\hline ARTHUR & $\begin{array}{c}2 \\
\text { (collapsed } \\
\text { from 6) }\end{array}$ & $\begin{array}{l}\text { Control (little employee } \\
\text { participation, little general } \\
\text { training, low wages, } 80 \% \\
\text { of employees on bonus or } \\
\text { incentives) ( } 53 \% \text { of } \\
\text { sample). }\end{array}$ & & $\begin{array}{l}\text { Commitment (moderate } \\
\text { employee participation, } \\
\text { moderate general } \\
\text { training, high wages, } 14 \% \\
\text { of employees on bonuses } \\
\text { or incentives) ( } 47 \% \text { of } \\
\text { sample). }\end{array}$ \\
\hline ICHNIOWSKI & 9 & $\begin{array}{l}\text { Traditional-union (fixed } \\
\text { job design, promotion } \\
\text { from within based on } \\
\text { seniority, grievance } \\
\text { procedures with } \\
\text { arbitration) (10\% of } \\
\text { sample) }\end{array}$ & $\begin{array}{l}\text { Union-like, do nothing, } \\
\text { complex (collectively, } \\
58 \% \text { of sample) (22\% of } \\
\text { sample wasn't classified) }\end{array}$ & $\begin{array}{l}\text { High commitment (flexible } \\
\text { job design, formal training } \\
\text { programs, internal } \\
\text { promotions, opinion } \\
\text { survey or information } \\
\text { sharing ( } 10 \% \text { of sample) }\end{array}$ \\
\hline $\begin{array}{l}\text { ICHNIOWSKI, } \\
\text { SHAW, and } \\
\text { PRENNUSHI }\end{array}$ & 4 & $\begin{array}{l}\text { System } 4 \text { traditional (strict } \\
\text { work rules, incentive pay } \\
\text { based on quantity not } \\
\text { quality, minimal employee } \\
\text { involvement, informal } \\
\text { training) (\% not reported) }\end{array}$ & $\begin{array}{l}\text { Systems } 2 \text { and } 3 \text { (mixed } \\
\text { between systems } 1 \text { and } \\
\text { 4) (\% not reported) }\end{array}$ & $\begin{array}{l}\text { System 1: Innovative } \\
\text { careful selection, } \\
\text { extensive training, team } \\
\text { problem solving, multi- } \\
\text { attribute gain-sharing, skill } \\
\text { based pay (\% not } \\
\text { reported) }\end{array}$ \\
\hline MacDUFFIE & 3 * & $\begin{array}{l}\text { Mass production (5\% of } \\
\text { employees in teams, little } \\
\text { quality control on shop } \\
\text { floor, little training, non- } \\
\text { contingent compensation, } \\
\text { extensive status, } \\
\text { differentiation) ( } 50 \% \text { of } \\
\text { sample) }\end{array}$ & $\begin{array}{l}\text { Transitional (between } \\
\text { mass and flexible } \\
\text { production systems on all } \\
\text { variables) ( } 25 \% \text { of } \\
\text { sample) }\end{array}$ & $\begin{array}{l}\text { Flexible production }(70 \% \\
\text { of employees in teams, } \\
\text { considerable job rotation, } \\
\text { extensive quality control } \\
\text { on shop floor, extensive } \\
\text { training, contingent } \\
\text { compensation, minimal } \\
\text { status differentials ( } 25 \% \\
\text { of sample) }\end{array}$ \\
\hline
\end{tabular}

- $\quad$ Based on MacDuffie's 3 scales: Buffers, Work Systems, and HRM Policies

\section{CONTINGENCIES}

Is there one best way to bundle human resource practices, or does it "all depend"? The preceding analysis would appear to support the former view, within the confines of the contexts studied and the limitations noted.

But, even the most fervent advocates of particular human resource strategies acknowledge that their preferred models are probably not always best. Ed Lawler, the high priest of the " High Involvement" model, for example, notes in his most recent book that this approach is "... not necessarily ... right ... for all environments and all societies" (Lawler, 1992, p. 
xiv). Similar positions are expressed, more or less firmly, by other dominant model theorists (e.g., Kochan and Osterman, 1994; Pfeffer, 1994). In brief, just about everybody who writes about human resource strategy subscribes to a contingency hypothesis to some extent.

And with good reason. Logically, as noted earlier, different organizational environments (e.g., those characterized by various combinations of business strategies, organizational structures, and process technologies [Dyer and Kochan, 1994]) should require both different types of employees and different types of behaviors from these employees. Further, different human resource strategies should produce both different types of employees and different types of behaviors from these employees. It therefore follows that a good match between human resource strategies and organizational environments should produce core capabilities which would enhance an organization's competitive position and, other things equal, result in greater organizational effectiveness (Cappelli and Singh, 1992; MacDuffie, in press; Schuler 1992; Schuler and Jackson, 1987).

A fill test of this theoretical perspective would require, in addition to reasonable hypotheses about specific relationships: (1) typologies or taxonomies of organizational environments and the nature of the people and behaviors required by each type, (2) typologies or taxonomies of human resource strategies (such as those noted above) and the nature of the people and behaviors produced by each type, and (3) comparisons of core competencies and/or organizational effectiveness across organizations which are characterized by high and low degrees of fit between "1" and "2". This is a complicated set of analyses, and so far no one has taken it on.

A couple of partial tests, involving two of the studies reported on earlier, have produced conflicting results.

Arthur (1990) examined the performance effects associated with fit between business strategy (the most commonly mentioned component of organizational environment) and human resource strategy in a preliminary analysis of his minimill data. He defined fit as occurring when a Cost-based business strategy was combined with a "Control-oriented" human resource strategy and when a Differentiation-based business strategy was combined with a "Commitment-type" human resource strategy. Obverse combinations constituted no-fit. He then hypothesized that the mills characterized by fit would have higher levels of productivity (i.e., fewer labor hours per ton of steel produced) and quality (i.e., lower scrap rates) and lower levels of employee turnover than those characterized by no-fit.

Selected data from his analysis are reproduced in Exhibit 4. Across the entire sample (27 mills), the expected differences appeared, but did not reach conventionally accepted levels 
of statistical significance. Among mills following a Differentiation-based business strategy, those with fit (11 mills) had 25\% higher productivity $(p<.10)$, $34 \%$ higher quality $(p<.10)$, and 67\% less employee turnover $(p<.05)$ than those with no-fit ( 8 mills). (No comparable analysis was possible for mills following a Cost-based business strategy since the no-fit cell contained only one case.) Overall, these results provide modest support for the contingency hypothesis.

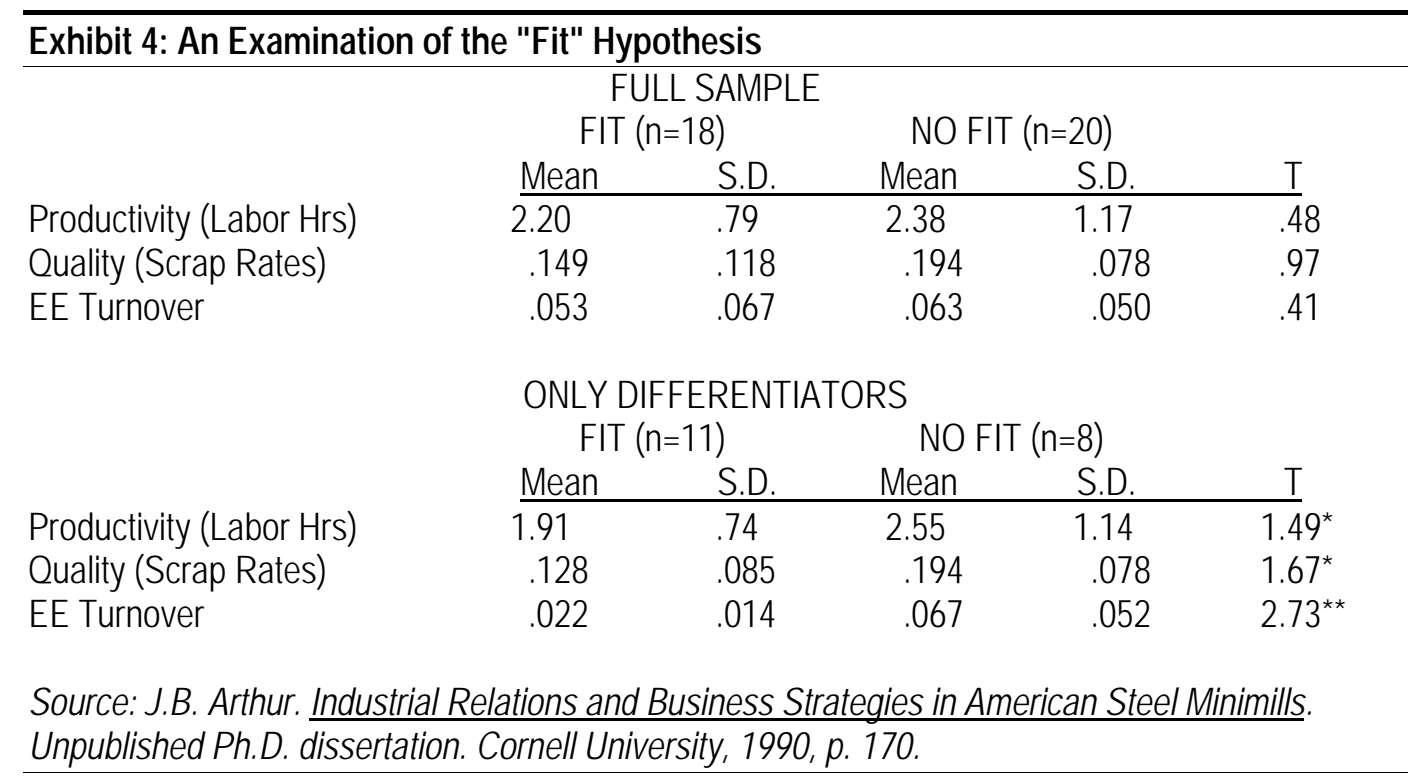

A different pattern of results emerged from an earlier analysis of the data from MIT's worldwide study of auto assembly plants (MacDuffie and Krafcik, 1992). The focus, again, was on productivity (i.e., labor hours per vehicle produced) and quality (i.e., defects per 100 vehicles). Fit was defined in terms of the linkage between human resource strategy and process technology (rather than business strategy as in the Arthur study). Representative results are shown in Exhibit 5 (MacDuffie and Krafcik, 1992). Consistent with the contingency hypothesis, the highest levels of productivity (22 hours per vehicle produced) and quality (49 defects per 100 vehicles) prevailed in high tech plants with "Flexible (or Lean) Production" human resource strategies. Also consistent with this hypothesis is the fact that performance falls off considerably in high-tech plants with a "Mass Production" human resource strategy. In contrast, however, the lowest levels of productivity (41 hours per vehicle produced) and quality (104 defects per vehicle) were found in low-tech plants with "Mass Production" human resource strategies. Further, performance in low-tech plants was considerably higher where "Flexible (Lean) Production" human resource strategies prevailed. Overall, these results provide strong support for the general superiority of the "Flexible (or Lean) Production" human resource strategy over 
the "Mass Production" human resource strategy in auto assembly plants (irrespective of the sophistication of the process technology), a conclusion seemingly out of sync with the contingency hypothesis.

\begin{tabular}{l}
\hline Exhibit 5: Another Examination of the "Fit" Hypothesis \\
\hline \\
\begin{tabular}{|c|c|c|}
\hline & Mass Production \\
HR Strategy & $\begin{array}{c}\text { Lean Production } \\
\text { HR Strategy }\end{array}$ \\
\hline High Tech & $P=30$ & $P=22$ \\
& $Q=79$ & $Q=49$ \\
\hline Low Tech & $P=41$ & $P=35$ \\
& $Q=104$ & $Q=73$ \\
\hline
\end{tabular}
\end{tabular}

\footnotetext{
$\mathrm{P}=$ Hours per vehicle

$\mathrm{Q}=$ Defects per 100 vehicles
}

Adapted from: J.P. MacDuffie and J.F. Krafcik. "Integrating Technology and Human Resources for High Performance Manufacturing: Evidence from the International Auto Industry". In T.A. Kochan and M. Useem (eds). Transforming Organizations (New York: Oxford University Press, 1992), $p$. 220.

As always, more research is needed. It could benefit from some prior theoretical work more precisely delineating not only the key components of the organizational environment, but also the human and behavioral requirements associated with various configurations of this environment. More conceptual work is also needed on the human resource strategy side (as noted above), including some attempt (beyond the very useful, but somewhat limited efforts of Schuler [1992] and Schuler and Jackson [1987]) to be more precise about the expected human and behavioral outcomes engendered by various strategies. The natural follow-on, then, would be more complete measures of organizational environments, as well as the inclusion of appropriate intervening human resource outcomes between these environments on the one hand and organizational and financial outcomes on the other.

\section{SUMMARY AND CONCLUSION}

In answer to the three questions initially posed:

(1) There are solid theoretical reasons for firms to bundle their human resource activities into identifiable strategies. How many actually do, even among a subset of their employees? The available data, which are sparse, suggest that the figure is probably no more than 20 percent generally, although it may go as high as 50 to 75 percent in some industries (e.g., steel minimills in the U.S., automobile assembly plants worldwide). How many bundles, or identifiable strategies, are there? Studies have turned up as few as three 
and as many as nine (although many of the latter appear to lack sufficient internal consistency to constitute real strategies). The problem is that the contents of these bundles vary quite a bit from study to study, primarily because there is so little consistency in the measures of human resource activities used to derive them.

(2) Bundles are superior to any of the individual human resource activities of which they are composed in enhancing and facilitating positive changes in productivity (Ichniowski, et al, 1993). But, not all bundles are created equal; some are clearly superior to others when it comes to reducing employee turnover (Arthur, 1994) and to enhancing productivity (Arthur, 1994; Ichniowski, 1990; Ichniowski, et al, 1993; and MacDuffie, in press), quality (Arthur, 1994; Ichniowski, et al, 1993; and MacDuffie, in press) and stock market performance (Ichniowski, 1990). The superior strategies are variously labeled "Innovative", "Commitment", and "Flexible (or Lean) Production". All incorporate a dimension of employee involvement, and a majority also involve careful selection, extensive training, and contingent compensation. It is possible, then, that culled and integrated they represent a particularly powerful human resource strategy.

But, probably not. Notwithstanding their similarities, these models differ in several important respects. Given this, it is perhaps just as likely that they reflect, to some extent anyway, underlying endogenous factors such as particularly salient management philosophies or careful management attention, somewhat analogous to the well-known Hawthorne effect.

(3) Few are those who argue with the general proposition that best results are attained when human resource strategies fit (or are linked with) extant business strategies and, perhaps, other elements of organizational contexts (Dyer and Kochan, 1994). It is, therefore, somewhat surprising to find that this proposition has received so little theoretical or, particularly, empirical attention. We found only a couple of relevant studies -- one (Arthur, 1990) generally supportive of the conventional wisdom, and the other (MacDuffie and Krafcik, 1992) not. 
Broadly, then, the only reasonable conclusion is that research into the effects of human resource strategies on organizational effectiveness, while promising, is still in its infancy. The studies are few in number, generally lacking in conceptual sophistication, and overwhelmingly focused on a shrinking component of the U. S. work force, namely blue-collar workers in heavy manufacturing. Thus, while there is every reason to believe that the strategic bandwagon will continue to roll, best to bear in mind the rather fragile empirical undercarriage on which it currently rests. 


\section{REFERENCES}

Arthur, Jeffrey. "Effects of Human Resource Systems on Manufacturing Performance and Turnover". Academy of Management Journal, Vol. 37, No. 4, 1994, pp. 670-687.

Arthur, Jeffrey. Industrial Relations and Business Strategies in American Steel Minimills. Unpublished Ph.D. dissertation, Cornell University, 1990.

Arthur, Jeffrey. "The Link Between Business Strategy and Industrial Relations Systems in American Steel Minimills". Industrial and Labor Relations Review, Vol. 45, No. 4, 1992, pp. 488-506.

Begin, James. Strategic Employment Policy: An Organizational Systems Perspective (Englewood Cliffs, NJ: Prentice-Hall, 1991).

Betcherman, Gordon, McMullen, Kathryn, Leckie, Norm, and Caron, Christina. The Canadian Workplace in Transition (Kingston, Ontario: Industrial Relations Centre Press, Queen's University, 1994).

Cappelli, Peter and Singh, Harbir. "Integrating Strategic Human Resources and Strategic Management" in David Lewin, Olivia Mitchell, and Peter Scherer (eds). Research Frontiers in Industrial Relations and Human Resources (Madison, WI: Industrial Relations Research Association, 1992), pp. 165-192.

Dunlop, John. "Organizations and Human Resources: Internal and External Markets" in Clark Kerr and Paul Staudohar (eds). Labor Economics and Industrial Relations: Markets and Institutions (Cambridge, MA: Harvard University Press, 1994), pp. 375-400.

Dyer, Lee. "Studying Human Resource Strategy: An Approach and an Agenda". Industrial Relations, Vol. 23, No. 2, 1984, pp. 156-169.

Dyer, Lee and Holder, Gerald. "A Strategic Perspective of Human Resource Management" in Lee Dyer (ed). Human Resource Management: Evolving Roles and Responsibilities (Washington, DC: Bureau of National Affairs, 1988), pp. 1-46.

Dyer, Lee and Kochan, Thomas. "Is There a New HRM? Contemporary Evidence and Future Directions". Paper presented at the conference "Managing Human Resources in the 1990s and Beyond: Is the Workplace Being Transformed?", Industrial Relations Centre, Queen's University, Kingston, Ontario, September 22-23, 1994. (Available as Working Paper No. 94-22, Center for Advanced Human Resource Studies, ILR School, Cornell University, Ithaca, NY).

Hackman, Richard. "Doing Research That Makes a Difference" in Edward E. Lawler III, et al (eds). Doing Research That Is Useful in Theory and Practice (San Francisco, CA: Jossey-Bass, 1985).

Ichniowski, Casey. "Human Resource Management Systems and the Performance of U. S. Manufacturing Businesses". National Bureau of Economic Research Working Paper No. 3449, September 1990. 
Ichniowski, Casey, Shaw, Kathryn, and Prennushi, Giovanna. "The Effects of Human Resource Management Practices on Productivity". Unpublished paper presented at the ILR School, Cornell University, September 13, 1993.

Kochan, Thomas and Osterman, Paul. The Mutual Gains Enterprise (Boston, MA: Harvard Business School Press, 1994).

Lawler, Edward E. III. The Ultimate Advantage: Creating the High Involvement Organization (San Francisco, CA: Jossey-Bass, 1992).

Lundy, Olive. "From Personnel Management to Strategic Human Resource Management". The International Journal of Human Resource Management. Vol. 5, No. 3, 1994, pp. 687-720.

MacDuffie, John Paul. "Human Resource Bundles and Manufacturing Performance: Flexible Production Systems in the World Auto Industry. Industrial and Labor Relations Review, in press.

MacDuffie, John Paul and Krafcik, John. "Integrating Technology and Human Resources for High-Performance Manufacturing: Evidence from the International Auto Industry" in Thomas Kochan and Michael Useem (eds). Transforming Organizations (New York: Oxford University Press, 1992), pp. 209-226.

Milliman, John, Von Ghnow, Mary Ann, and Nathan, Maria. "Organizational Life Cycles and Strategic International Human Resource Management in Multinational Companies: Implications for Congruence Theory". Academy of Management Review, Vol. 16, No. 2 , 1991, pp. 318-339.

Pfeffer, Jeffrey. Competitive Advantage Through People (Boston, MA: Harvard Business School Press, 1994).

Schuler, Randy. "Strategic Human Resource Management: Linking the People With the Strategic Needs of the Business". Organizational Dynamics, Summer 1992, pp. 18-31.

Schuler, Randy, Dowling, Peter, and De Cieri, Helen. "An Integrative Framework of Strategic International Human Resource Management". Journal of Management. Vol. 19, No. 2, 1993, pp. 419-459.

Schuler, Randy and Jackson, Susan. "Linking Competitive Strategies With Human Resource Management Practices". Academy of Management Executive, Vol. 1, No. 3, 1987, pp. 207-219.

Walton, Richard. "From Control to Commitment in the Workplace". Harvard Business Review, March-April 1985, pp. 77-84. 